\title{
0-081当科における手術加療を行った鼻副鼻腔真菌症症例の検討
}

○宮本秀高、田中秀峰、田中晴香、原＼cjkstart晃

筑波大学 耳鼻咽㑨科・頭頸部外科

近年、鼻副鼻腔真菌症は増加傾向にあり、無症候性に他科の検查で偶発的に発見されることがある。2012年 1 月から 2016 年12月までに当科で内視鏡下鼻副鼻腔手術を行い、病理組織検査にて鼻副鼻腔真菌症と診断した53症例について検討を行っ た。検討項目は年齢、性別、主訴、発症契機、病型、罹患副鼻腔、基礎疾患、診断方法、治療、予後、症例数の年次变化と し、諸家の報告と比較検討を行った。特に症例数の年次変化に注目すると2014年以降急増していた。当科においては2012年 以降鼻副鼻腔疾患に対する専従スタッフの充実とともに、2014年以降、鼻副鼻腔真菌症が疑われた場合、無症候性でもでき る限り手術の方針を徹底し、罹患副鼻腔の開放および真菌塊の完全除去を行っている。また同時に他病院、医院、他科への 治療方針の周知も徹底しており、これまで無症候性であり加療されていなかった鼻副鼻腔真菌症の発見、治療導入が年次症 例数の増加に寄与していると考えた。

\section{0-082 当科における鼻副鼻腔内反性乳頭腫症例の検討}

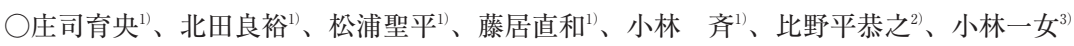
昭和大学藤が丘病院 耳鼻咽喉科 ${ }^{12}$ 、神尾記念病院 耳鼻咽喉科 ${ }^{2}$ 、昭和大学 医学部 耳鼻咽喉科学講座 ${ }^{3)}$

鼻副鼻腔乳頭腫は鼻副鼻腔に発生する良性腫瘍のなかで最も頻度が高い。良性腫瘍ではあるが、約10-15\%の症例で悪性 腫瘍が混在していると報告されており、また容易に再発することが知られている。これらの特徵から、以前は悪性腫瘍に準 じた手術（Denker 法や lateral rhinotomy など）が行われていた。しかし、近年の内視鏡下鼻内副鼻腔手術（ESS）の手技 や機器の進歩により、鼻副鼻腔内反性乳頭腫に対して ESS が適用されるようになってきた。

当科においては、Krousの stage 分類で T2 までの症例であれば経鼻アプローチを用い、 $\mathrm{T} 3$ 以上の症例であれば症例に応 じて、経鼻に加えて歯齫切開など外切開によるアプローチを併用している。腫瘍は可能な限り一塊に摘出をした上で、基部 の処理を的確に行うよう心掛けている。また腫瘍細胞の播種を防ぐため、マイクロデブリッダーは極力使用しないようにし ている。

2014年 8 月から 2016 年 8 月までの 2 年間に当院で手術を行い、経過観察中の鼻副鼻腔内反性乳頭腫23例について検討を行 ったので報告する。

\section{0-083＼cjkstart慢性浸潤型副鼻腔真菌症における $\beta-\mathrm{D}$ グルカン測定の有用性}

○大庭亜由子、伊藤 伸、岡田弘子、安齋 崇、池田勝久

順天堂大学 耳鼻咽喉科学講座

副鼻腔真菌症は浸潤型と非浸潤型に大別され、浸潤型は急性、慢性（非肉芽腫）、慢性肉芽腫性の 3 つに分類される。急 性浸潤型は急激に進行する経過、肉眼的には蒼白な壊死粘膜を呈する。慢性浸潤型は慢性の経過、非浸潤性（寄生型）真菌 塊と類似する肉眼的所見、糖尿病またはステロイド使用などの免疫低下の背景因子を有する。一般的に浸潤型真菌感染症の

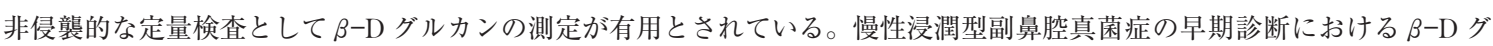
ルカン測定の有用性を検討した。過去 5 年間で経験した副鼻腔真菌症の手術症例のうち、慢性の経過を示し免疫低下の背景 因子を有したものは15例、そのうち術前 $\beta-\mathrm{D}$ グルカンの異常高值は 5 例に認め、さらに手術病理検体で粘膜への真菌の浸 潤を認めた症例は 2 例であった。現在浸潤型副鼻腔真菌症の診断は病理所見を証明することであるが、組織材料に依存して おり簡便な早期診断に限界がある。 $\beta-\mathrm{D}$ グルカン測定により術前の早期診断が可能と考えられる。

\section{0-084 術式選択に検討を要した若年性鼻咽頭血管線維腫の 2 例}

横井秀格1)、児玉 悟(2)、松本祐磨1)、川田往嗣1)、山中英敬1)、齋藤康一郎1)

杏林大学 医学部 耳鼻咽喉科学教室 ${ }^{1)}$ 、大分大学 医学部 耳鼻咽喉科学教室 ${ }^{2)}$

（はじめに）若年性鼻咽頭血管線維腫は、血流に富む良性腫瘍である。今回われわれは、内視鏡下鼻内手術のみにて摘出 した症例 1 : Radlkowski 分類： stage IIA と内視鏡下および上頡洞前壁に小さな孔と鼻腔対側を含めた multi-portal approach にて摘出した症例 $2 ：$ stage IIC を経験したので報告する。（症例 1 ）26歳男性。画像にて左上咽頭から後鼻腔に主 座を持ち、一部左側翼口蓋窩と蝶形骨洞に進展していた。血管塞栓術後、内視鏡下腫瘍摘出術を施行した。（症例 2 ） 12歳 男性。画像にて、術前に腫瘍は左鼻腔を占拠し、翼口蓋窩から側頭下窩に進展していた。血管塞栓術後、ワーキングスペー スを得るために multi-portal approach にて摘出した。(まとめ) 若年性鼻咽頭血管線維腫の手術に際して、翼突管動脈に注 意が必要であった。低年齢で腫瘍が外側への進展を認める際は、multi-portal approach が有用であり、コブレーターの使用 が効果的であった。 


\section{0-085＼cjkstart鼻副鼻腔内視鏡下手術における前上歯槽神経の上顎洞内露出例}

○久満美奈子、枝川久美子、大塚雄一郎、鳳田耿子

千葉市立海浜病院

上顎洞手術において、Caldwell-Luc 法など上顎洞前壁骨を削開して上顎洞粘膜を剥離除去する術式では、眼窩下神経の 保護のみならず、術後の歯牙異常感を予防するために、歯牙の支配神経である上歯槽神経叢を傷つけない上う上顎洞前壁外 側や下方の骨、梨状口縁を削除しすぎないことが重要である。一方内視鏡下副鼻腔手術では、上顎洞内を操作する際は中鼻 道経由で行われることが多く、通常上䫟洞前壁内を走行する前上歯槽神経は意識されない。今回われわれは上顎洞内反性乳 頭腫に対する endoscopic medial maxillectomy(EMM) において上顎洞内腔前壁に露出した前上歯槽神経を確認した。上顎 洞内に露出して走行する前上歯槽神経はまれであるが、上顎洞前壁の骨削開を伴わない内腔の剥離操作のみでも容易に損傷 される可能性があり、EMM や下鼻道対孔作成による上顎洞内の操作時には注意が必要である。若干の文献的考察を加えて 動画とともに報告する。

\section{0-086＼cjkstart経眼窩内視鏡アプローチが有用であった眼窩外側病変}

○田中秀峰 ${ }^{1)}$ 、宮本秀高 ${ }^{1)}$ 、佐々木 薰 ${ }^{2}$ 、田中晴香 ${ }^{1)}$ 、原 晃 ${ }^{11}$

筑波大学 耳鼻咽喉科 ${ }^{12}$ 、筑波大学 形成外科 ${ }^{2}$

眼窩外側病変に対して、経鼻内視鏡アプローチでは眼窩組織や眼窩下神経があるために困難を極める。症例は、30歳台女 性。約 1 年前に両側外転神経麻疩による複視にて発症した蝶形骨斜台部を中心としたアレルギー性真菌性鼻副鼻腔炎に対し て経鼻内視鏡手術を受けていた。この時すでに蝶形骨翼状突起から大翼へ進展し左眼窩外側に広がる軟部陰影を認めていた ため、経翼口蓋窩にアプローチしたが眼窩組織や眼窩下神経のために到達できなかった。術後に複視は消失したが、術後 5 カ月ごろから左㚘部痛やしびれが出現し、内服薬でコントロール不良となった。眼窩外側病変による眼窩下神経の圧迫症状 と考えられた。結膜切開による経眼窩内視鏡アプローチによる病変除去を行った。術後に煩部痛やしびれは消失し、経過良 好であった。眼㸗外側病変に対して経眼窩内視鏡アプローチは安全で有用なアプローチ法と考えられ、術中画像を供覧す る。

\section{0-087＼cjkstart眼窩先端部海綿状血管腫に対する内視鏡下経鼻的眼窩手術の経験}

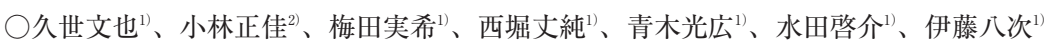

岐皁大学 医学部 耳鼻咽喉科 ${ }^{1}$ 、三重大学 医学部 耳鼻咽喉・頭頸部外科 ${ }^{2}$

【はじめに】眼窩内病変のうち、内側と下部に存在するものに対しては経鼻的にアプローチが可能とされている。今回、 鼻内内視鏡下で施行した眼窩内腫瘍摘出術の経験を報告する。【症例】61歳男性。59歳頃より徐々に右視力低下を来したた め眼科を受診し、視神経障害を指摘された。造影 MRI にて右眼窩先端部に 17 ミリ大の腫瘤を認め、海綿状血管腫が疑われ た。腫瘤は視神経の内側下部に存在し、脳外科との検討の結果、経鼻的に摘出術を行う方針とした。【結果】まず鼻中隔矯 正と各副鼻腔開放でワーキングスペースを確保した。ナビゲーションシステムで確認しながら眼窩紙様板を外した。骨膜切 開し、腫瘍前端を露出後、眼窩内脂肪、内直筋、下直筋との癒着を認めたが、3-handed technique を駆使して剥離し、摘 出した。出血は微量であった。術後視力の悪化や眼球運動障害は認めなかった。結論】眼窩の内側、下部に存在し、視神 経と離れている良性腫瘍には経鼻的な眼窩手術は良い適応であると考える。

\section{0-088 当院で内視鏡下視神経管開放術を施行した外傷性視神経管骨折の 5 例}

○猪狩雄一 ${ }^{1)}$ 、小澤宏之 ${ }^{1)}$ 、齋藤 真 ${ }^{1)}$ 、伊藤文展 ${ }^{1)}$ 関水真理子 ${ }^{1)}$ 、太田 優 ${ }^{2}$ 、戸田正博 ${ }^{3)}$ 、小川 郁 ${ }^{1)}$ 慶應義塾大学 医学部 耳鼻咽喉科学教室 ${ }^{11}$ 、慶應義塾大学 医学部 眼科学教室 ${ }^{2}$ 、 慶應義塾大学 医学部 脳神経外科学教室 ${ }^{3}$

視力低下を伴う外傷性視神経管骨折では早急な外科的治療を勧める報告があるが、画像検查での骨折部位の確認が困難な 症例が多く、手術適応や時期について統一的な見解はない。当院では外傷性視神経管骨折に対して眼科、脳神経外科との千 ームサージャリーにより積極的な視神経管開放術を行っている。今回、当施設で外傷性視神経管骨折に対して内視鏡下視神 経管開放術を行った 5 例について報告する。 5 例の内訳は年齢17～78歳で、 5 例すべてに眉毛部外側に外傷を認めた。術前 視力は全盲〜0.2で、視野欠損は 5 例すべてで認めた。術前 CT で骨折線を認めた症例は 1 例であった。受傷から手術まで の待機期間は19時間〜 6 日であった。治療は内視鏡下視神経管開放術㧍よびステロイドパルス療法を施行した。 5 例すべて で術中に視神経管骨折を認めた。 4 例で術後の視力、視野は改善したが、受傷 6 日後に手術した 1 症例では改善しなかっ た。眉毛部外側に外傷を認める症例では視神経管骨折の可能性が高く、早期の視神経管開放術およびステロイドパルス療法 が有効である可能性が示唆された。 


\section{0-089 鼻中隔矯正術後に open septorhinoplasty による再手術を要した症例の検討}

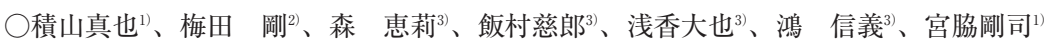

東京慈恵会医科大学附属病院 形成外科学講座1、東京慈恵会医科大学附属第三病院 形成外科学講座2)、

東京慈恵会医科大学附属病院 耳鼻咽喉科 ${ }^{3}$

【目的】当施設では鼻の機能と整容の改善の目的で耳鼻咽喉科と合同で open septorhinoplasty（以下 OSRP）を施行して いるが、症例を重ねることで鼻中隔矯正術後の再手術症例を多く経験し、その原因を検討する。【方法】2007年から2016年 で鼻中隔矯正術後に再手術を要した 25 例を対象とし、手術に至った原因と対処法を後向きに調查した。【結果】再手術に至 った原因は、鼻閉の残存が17例、外鼻変形が18例（重複10例）であった。さらに、鼻閉の残存の内訳は、温存した L-Strut の弯曲残存が14例と多く、内鼻弁狭窄は10例（重複 7 例）であった。外鼻変形の内訳は、もともと斜鼻があり術後に外鼻形 成依頼となったものが 6 例、鼻中隔矯正術後に鞍鼻変形を来したものが12例であった。【考察】従来の鼻内法での鼻中隔矯 正術では、温存する L-Strut 自体の弯曲や内鼻弁狭窄の対応は困難であり、鼻閉が残存する可能性がある。また、温存した

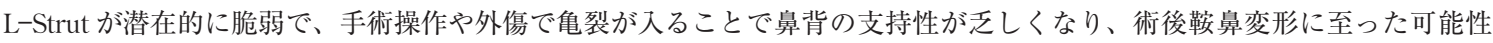
がある。

\section{0-090 好酸球遊走における PGD2 の影響}

齋藤秀和、本田耕平、山田武千代

秋田大学 医学部 医学系研究科耳鼻咽喉科頭頸部外科学講座

【目的】 PGD2 は好酸球遊走活性作用を持つことはいぜんより報告されている。しかし、PGD2のレセプターである、 DP1、CRTH2 を介する作用は報告により異なっている。今回われわれは、PGD2 の作用をヒト好酸球を用い、リアルタイ ム細胞動態観測装置（TAXIScan）にて解析する。【方法】ドナーより採血で得られた血液から CD16 negative selection 法に て好酸球を採取した。また、手術時に得られた鼻茸を粉砕し抽出液を用いて遊走活性物質とした。好酸球の遊走はTAXIScan を用いて観察した。PGD2 のレセプターである、DP1、CRTH2 のアンタゴニストを用いて、その作用を観察した。ま た、採血データなどの患者背景と比較した。【成績】 PGD2への遊走は CRTH2 アンタゴニストで有意に抑制され、DP1ア ンタゴニストで有意な差は出なかったが抑制される傾向があった。しかし、鼻茸抽出液への遊走はこれらのアゴニスト、ア ンタゴニストいずれにおいても有意な抑制を受けなかった。結論】生体内では PGD2 系のみのブロックでは好酸球の集積 を抑制できないと考えられた。

\section{0-091スギ花粉症における IL-35 の役割と SLIT 後の動態について}

$\bigcirc$ 神前英明 ${ }^{1)}$ 、有方雅彦 ${ }^{1)}$ 、湯田厚司 ${ }^{2)}$ 、清水猛史 ${ }^{1)}$

滋賀医科大学 医学部 耳鼻咽喉科 ${ }^{11} 、$ ゆたクリニック2

【目的】 IL-35 は、免疫・炎症抑制作用に関与し、制御性 T細胞、樹状細胞、制御性 B 細胞などから産生される。スギ花 粉症における IL-35 の生物活性ならびにスギ花粉症患者 SLIT 後の IL-35 の動態や臨床症状との関連について検討した。【方 法】スギ花粉症患者の末梢血単核球（PBMC）にスギ粗抗原および rIL-35を加えて培養しサイトカイン産生を検討した。 スギ花粉症患者 SLIT 前後の PBMC をスギ粗抗原で刺激し、制御性 T 細胞、単球、B 細胞中の IL-35 陽性細胞の割合を解析 した。さらに、スギ花粉症患者 SLIT 後の花粉飛散期に扔ける、血清中 IL-35 と臨床症状の関連について検討した。結果】 rIL-35 投与で IL-5、IL-17、IFN- 産生が抑制され、IL-10 産生は増加した。SLIT 前後では制御性 T 細胞における IL-35 陽 性細胞数は増加した。スギ花粉飛散期に扔けるSLIT 後の血清中 IL-35 濃度と症状薬物スコアの間には負の相関がみられた。 【結論】IL-35 は免疫・炎症反応に対する抑制効果を有し、SLIT 後のスギ花粉飛散期の症状抑制にかかわっているかもしれ ない。

\section{0-092 スギ花粉症に対するアレルゲン皮下免疫療法患者を対象とした ELIFAB 測定系の確立}

○松岡伴和 ${ }^{1)}$ 、深野千陽 2 、中尾篤人 ${ }^{3)} 、$ 土井雅津代 ${ }^{2)}$ 、増山敬祐 ${ }^{1}$

山梨大学医学部耳鼻咽喉科 ${ }^{12}$ 、鳥居薬品株式会社研究所 ${ }^{21}$ 、山梨大学医学部免疫学講座 ${ }^{3)}$

アレルゲン免疫療法（AIT）はスギ花粉症の対して有効な治療法であるが、その作用機序は明らかになっていない。本研 究では、AIT 作用機序の一つとしてB細胞の抗原提示能に着目し、スギ花粉アレルゲン (JCP) を用いた Enzyme-Linked Immunosorbent Facilitated Antigen Binding(ELIFAB) の測定系を確立した。B細胞表面にある低親和性 IgE 受容体である $\mathrm{sCD} 23$ をプレコートレ、アレルゲンである JCP $(0 \sim 100 \mu \mathrm{g} / \mathrm{mL})$ と患者血清を用い、JCP-IgE 複合体と sCD23 の結合性を 評価した。スギ花粉症患者血清の中で最も $\mathrm{sCD} 23$ と高結合を示す血清を陽性血清（indicator serum）として用いた。最適 な反応を示したのは、 $\mathrm{sCD} 23$ 濃度 $20 \mu \mathrm{g} / \mathrm{mL}$ と JCP 濃度 $0.3 \mu \mathrm{g} / \mathrm{mL}$ であった。JCP を用いた ELIFAB の測定系を構築した。 本測定系は、今後のスギ花粉症に対するAIT の作用機序解明の一助になると考えられる。 